\title{
1 Poetry as autobiography
}

\section{Introduction}

'This To Do' is a frequently overlooked poem in R. S. Thomas's 1966 collection Pieta. Although appearing twenty years into Thomas's career as a published poet, Pieta effectively ends the early periods of work at Manafon (1942-54) and Eglwysfach (1954-67) and simultaneously initiates the succeeding periods at Aberdaron (1967-78) and Rhiw (1978-94) on the Llŷn peninsula in north Wales. The collection falls not only within a geographical transition for the poet but at a major thematic cross-roads as well. The move to Aberdaron in 1967 marks in Thomas's work a gradual letting go of his long absorption and wrestling with the life of the upland farm communities and, if not his actual insistence, at least his poetic insistence on a personal and national Welsh identity. ${ }^{1}$ The poetry of Aberdaron and later Rhiw is conspicuously 'ingrowing'. It depicts an altogether inward and downward metaphysical probing of the nature of deity and of the individual self. Of course in one sense Thomas has always been a poet of interiors, and yet it seems clear that the poems of the Aberdaron period contribute increasingly toward a sustained project in autobiography. My suggestion here is not that Thomas begins a project in poetic autobiography after moving to Aberdaron, but more that, for Thomas, poetry, by its very definition, is autobiography. The poems written after the move to Aberdaron illustrate a significant acceleration and intensification of that autobiographical instinct.

In this first chapter my technique will be to explore the idea of poetry as autobiography using Thomas's poem 'This To Do', but also introducing the work of a fairly wide range of other major writers who, while perhaps not directly influential on Thomas's work, have nevertheless undertaken similar projects in their own writing and thus become a loose context in the light of which Thomas's work in this area becomes more clear. I rely most heavily here upon Montaigne's writings in his Essays and on much of the prose work of Seamus Heaney. I also suggest specific parallels in the theoretical work of Charles Olson and Wallace Stevens, and in the poetry of Derek Walcott. In addition to these parallels I want also 
to suggest that Thomas's 'project' in autobiography has much in common with Carl Jung's theories of the subconscious and unconscious as he writes of them in his Memories, Dreams, Reflections (1961). Chapter 2 is devoted almost exclusively to a detailed investigation of Thomas's poems as a guide to the crucial aspects of his own project of poetic autobiography.

\section{'The door to myself'}

'This To Do' (Pieta, 1966) is a good place to start, not only because it falls 'on the cusp', as it were, of Thomas's geographical move and a corresponding intensification of the autobiographical instinct but because it says something about what poetry as autobiography is for R. S. Thomas. Despite its forward-looking title, the poem functions as a kind of anchor and pivot in the oeuvre, echoing a process which underlies the prior work while consciously reaffirming a purpose in writing which may have been more or less unconscious up to this point. Thus the poem consolidates, foregrounds, and, in some ways, reinitiates the ongoing project of autobiography in Thomas's work, what I refer to here as the 'project of the self'. The poem begins:

I have this that I must do

One day: overdraw on my balance

Of air, and breaking the surface

Of water go down into the green

Darkness to search for the door

To myself. (12)

Underpinning the poem as a whole is an experience of dislocation or alienation in which a 'surface self' is clearly conscious of an alternate hidden or 'buried self', the recovery of which is fraught with difficulty and danger. The opening phrase 'I have this that I must do / One day' is at once direct, determined, and yet tinged with vague misgiving, with dread and with an actual indeterminacy. Thomas accepts the search as both uniquely his own and imperative, and yet the enjambment of 'one day' creates a doubling back effect, a recoil from the bold approach of the opening line so that a reader is presented with knowledge and purpose as well as, in Kierkegaard's words, fear and trembling. The final lines of the poem reiterate this ambivalent opening and add to it an acknowledgement of the courage and sacrifice necessary for the discovery of the hidden door to the self: 
I must go down with the poor

Purse of my body and buy courage,

Paying for it with the coins of my breath.

This project of the self is not a literary rendering of the ego, an aim asserted by Pound and Eliot as the hallmark failure of the Romantic period. It is precisely the wounded ego here which recognises its alienation, its incompletion. Thomas's project is one which seeks a reversal of the birth sequence, a passage back to the womb. Comfortable balances of air are disrupted in the process, the light abandoned. According to the poem the passage back to the door of the self requires a negation of the air-element natural to the poet. He ceases to breathe and must live on gulped reserves of oxygen in the green dark. In this sense the state of original alienation is not wholly one of discomfort: the poet lived at the surface of life, breathing, balanced, hearing and seeing. The descent to search for the door to the self entails a forfeiture of such normal 'comforts', an initiation into 'dumbness and blindness / And uproar of scared blood / At the eardrums'.

Thomas's metaphor of submersion and underwater exploration implies not only a surface alienation but a revisiting of lost sources in the self which can, if only temporarily, counteract that alienation. The search is essentially hopeful and aimed at a reunification of the divided self. The poet's perilous descent into the land of the dead where 'the slow corpses / Swag' is also a descent toward some life-giving force. ${ }^{2}$ Though the poet is 'dumb' in the process of the dive, he must still return to his surface life, to air, light, and speech. Thus the poems become a narrative of these repeated forays into the self; brief illuminations of lost sources. Poetry in this manner becomes both the product of search and the search itself. It becomes the breathing space, as the American poet Charles Olson would claim, the breath itself, the respiration of the poet. ${ }^{3}$

If Thomas's poetry is an underwater archaeological excavation of the self, the unity he achieves over alienation, though repeatable, can only be temporary. The fragments of the divided self remain touchstones for each other but can enjoy no permanent reunion such as that anticipated in Derek Walcott's 'Love after Love' from his 1976 collection Sea Grapes:

The time will come when, with elation, you will greet yourself arriving at your own door, in your own mirror, and each will smile at the other's welcome and say, sit here. Eat. (328) 
Walcott implies a dislocation and search clearly similar to Thomas's. The difference however lies in Thomas's lack of closure and 'elation' as the self and the other re-adhere. Walcott ends 'Love after Love' with the line: 'Sit. Feast on your life.' For Thomas the comfort afforded by this kind of epiphany is never realised. Thomas's project of the self is achieved in endless returns, in 'spending the coins of the breath from the body's poor purse', in revisiting the lost sources at cost, over and over again. ${ }^{4}$

This idea of poetry as the product of endless returns to the door of the self is approached from a slightly different angle in Thomas's 'Introduction' to the Penguin Book of Religious Verse (1963). There Thomas 'roughly' defines religion as 'embracing an experience of ultimate reality', and poetry as 'the imaginative presentation of such' (64). According to these qualifications poetry becomes, for Thomas, the imaginative presentation of an experience of ultimate reality. In the light of Christ's declaration that 'the Kingdom of God is within you', it becomes natural to equate Thomas's experiences of ultimate reality with the subaqua encounters at the door of the self. This is not something new to poetry. It is essentially a harking back to the words of the Oracle of Apollo at Delphi: 'Gnothi seauton', know thyself, which later became the Socratic dictum and the seed of the notion of the daimon as teacher and guide. In sixteenth-century France 'gnothi seauton' becomes, for Montaigne, the leading principle of his Essays:

What does Socrates treat more amply than himself? And what does he most often lead his pupils to do, if not to talk about themselves - not about what they have read in their books but about the being and movement of their souls? (1991: 425)

This talking about the being and movement of the soul is not something put forth as stored knowledge, not a series of careful revelations. The being and the movement are those things which poetry, like the Socratic dialogues, discovers as poetry happens. In his 1978 lecture 'The Makings of a Music' Seamus Heaney describes this as

a version of composition as listening, as a wise passiveness, a surrender to energies that spring within the centre of the mind, not composition as an active pursuit by the mind's circumference of something already at the centre. (1980:63)

Heaney's use of the words 'surrender' and 'spring' points to a delicate immediacy, a simultaneous cause and effect in the process of poetry as autobiography. Though the poem recounts, in Thomas's words, an 
experience of ultimate reality, the poem is, simultaneously, an integral part of the experience itself. For all three writers, Montaigne, Heaney, and Thomas, that experience becomes not only central but religious in significance, requiring a conscious turning away from the emptiness of exteriors in order to be realised. In his essay 'On Vanity' Montaigne makes his most emphatic discourse on this idea. One can hear in the essay the same chords Thomas strikes in 'This To Do':

We are swept on downstream, but to struggle back towards our self against the current is a painful movement; thus does the sea, when driven against itself, swirl back in confusion. Everyone says: 'Look at the motions of the heavens, look at society, at this man's quarrel, that man's pulse, this other man's will and testament' - in other words always look upwards or downwards or sideways, or before or behind you. That commandment given us in ancient times by that god at Delphi was contrary to all expectation: 'Look back into your self; get to know your self; hold on to your self'. Bring back to your self your mind and your will which are being squandered elsewhere; you are draining and frittering yourself away. Consolidate your self; rein your self back. They are cheating you, distracting you, robbing you of your self. (1991: 1132)

Montaigne suggests the distinguishing characteristic and natural inclination of humanity to be a capacity for self-division or alienation. Also in keeping with Thomas, Montaigne claims that the process of reunification, of healing of such fragmentation, entails a 'painful movement' against such tides. But where Montaigne proves particularly helpful is in his articulation of why such a painful movement toward reunification of the divided self is important. The verbs Montaigne uses to describe the man who refuses to know himself are translated as 'squander', 'fritter', and 'drain', verbs of dispersal and of lessening which imply that the alienated self is being spent in a gradual thinning of powers. Not knowing its centre, the self achieves a splintering process which can end only in annihilation. The project of the self as a counter-activity to such inertia is a search and discovery, a grappling with sources of being and identity which, while painful, is ultimately a matter of self-preservation. For Thomas and Montaigne it is only in this way that one achieves any sense of one's proper place and purpose in life. It is only in this way that one comes to know the authentic identity on which human happiness is continually predicated. ${ }^{5}$

Neither Montaigne nor Heaney underestimates the difficulties involved in the project of the self. Montaigne writes of these difficulties 
in a passage from his 'On Practice' which becomes an excellent portrait of the poet's work and life:

It is a thorny undertaking - more than it looks - to follow so roaming a course as that of our mind's, to penetrate its dark depths and its inner recesses, to pick out and pin down the innumerable characteristics of its emotions. It is a new pastime, outside the common order; it withdraws us from the usual occupations of people - yes even from the most commendable ones. (424)

Unlike Montaigne, Heaney writes in his 1974 lecture 'Feeling into Words' of the project of autobiography more specifically in terms of poetry and its exploration of a buried life:

poetry as divination, poetry as revelation of the self to the self, as restoration of the culture to itself; poems as elements of continuity, with the aura and authenticity of archaeological finds, where the buried shard has an importance that is not diminished by the importance of the buried city; poetry as a dig, a dig for finds that end up being plants. (1980: 41)

While this reiterates much of what Thomas describes in 'This To Do', Heaney refers here to 'elements of continuity'. The kind of intense struggle evidenced in Montaigne and more acutely in Thomas is, I think, conspicuously absent in Heaney. Like Wordsworth, Heaney not only seems capable of easier reconnections with 'sources', but the selves in Heaney appear fewer and more grounded, less shifting and elusive than the often myriad selves which emerge in Thomas's poems. For example, Heaney, in his 1966 poem 'The Diviner' from his first volume Death of a Naturalist, likens the poet's rediscovery of such sources to the water diviner's gift with the forked hazel, 'circling the terrain, hunting the pluck / Of water', feeling in his veins and flesh its course under the earth (1966: 48). Subsequently, in 'Feeling into Words', Heaney calls this the 'gift for being in touch with what is there, hidden and real' (1980: 47). Using slightly different imagery Heaney also 'finds' himself in texture of the felt earth and the action of digging. ${ }^{6}$ In 'Bogland', from his collection Door into the Dark (1969) he writes: 'Our pioneers keep striking / Inwards and downwards' (41). The element here is earth, bog, and the movement is through layers of the sedimentary self. Again, in 'Feeling into Words' (1974) Heaney admits: 'When I called my second book Door into the Dark I intended to gesture towards this idea of poetry as a point of entry into the buried life of the feelings' (1991: 52). But in contradistinction to Heaney's images of accessing the 'buried life', Thomas's 
images are characteristically fluid and shifting: the murky sea, the clouded sky, the shifting mirror.' For example, Thomas writes in 'Reflections' from No Truce with the Furies (1995) that

The furies are at home

in the mirror; it is their address.

Even the clearest water,

if deep enough can drown. (31)

This kind of resignation to a confrontation with the furies in the mirror, the many selves all seemingly pitted against the poet, is typical in Thomas's work, not a vocalisation of the Romantic first-person stance but a more Modernist grappling with multiple elusive identities. While he writes in the final stanza of the poem of the mirror as a chalice, significantly it is one

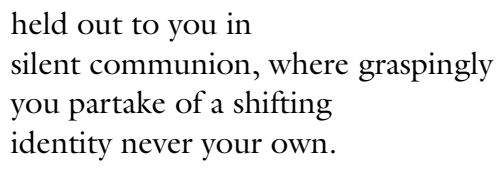

held out to you in silent communion, where graspingly you partake of a shifting identity never your own.

One feels that Thomas's discoveries of an inner identity or source, when they do occur, are won by bitter toil rather than received as gift, as in Heaney. Wallace Stevens writes in his 1942 lecture 'The Noble Rider and the Sound of Words' that nobility in poetry is not artifice of the mind but is

a violence from within that protects us from a violence without. It is the imagination pressing back against the pressure of reality. It seems, in the last analysis, to have something to do with our selfpreservation; and that, no doubt, is why the expression of it, the sound of its words, helps us to live our lives. (1951: 36)

And though Heaney, in his 1989 lecture 'The Redress of Poetry', refers to this selection from Stevens, the ideas seem characteristic more of Thomas's project than of Heaney's: the violence within, the pressing back, the self-preservation. ${ }^{8}$ Montaigne writes in 'On Practice', 'I can think of no state more horrifying or more intolerable for me than to have my Soul alive and afflicted but with no means of expressing herself' (1991: 421). Such a statement foregrounds one of the differences between Heaney's project and Thomas's. Thomas's poetry grows out of the intolerability of mute affliction. It seems that his soul, suffering a chronic fragmentation and alienation, strives towards discovery through expression. ${ }^{9}$ Conversely, Heaney's project grows out of the hidden spring 
that swells in gift, and accordingly his work is more the celebration of discovery than the dire angst of often frustrated pursuit.

Two final distinctions and one final note will help distinguish this notion of poetry as autobiography in $\mathrm{R}$. S. Thomas, the first a distinction between craft and technique, the second a distinction between will and waiting, and the note an effort to locate the project of the self in its significantly wider context.

In 'Feeling into Words' (1974) Heaney offers a subtle insight into the nature of the poetic project of the self by distinguishing between definitions of craft and technique. He defines craft as

what you can learn from other verse. Craft is the skill of making. It wins competitions in the Irish Times or the New Statesman. It can be deployed without reference to the feelings or the self. It knows how to keep up a capable verbal athletic display. (1980: 47)

Craft is formal skill in the expression of poetry, without reference to the project of the self. And yet earlier I suggested that poetry as autobiography consists in a kind of instantaneous, simultaneous listening, discovery and expression; that the listening and the discovery are inherent in and inseparable from the expression. Thus while craft is a vital force brought to bear primarily in the expression of poetry, it remains, in Heaney's holistic view, equally dependent upon the hearing and the finding as well. Without craft the poetic project of the self is certainly not impossible but is, for Heaney, significantly crippled. Conversely, technique, Heaney suggests, is the experience of the well bucket caught when 'the chain draws unexpectedly tight and you have dipped into waters that will continue to entice you back. You'll have broken the skin on the pool of yourself' (1991: 47). Technique is an experience at the hidden door to the self. Heaney claims it involves for the poet 'a definition of his own reality ... a dynamic alertness that mediates between the origins of feeling in memory and experience and the formal ploys that express these in a work of art' (1991: 47). It becomes possible of course that either side of such an equation might prove weak, that is, that one might understand and utilise formal ploys but lack an alertness to 'the origins of feeling in memory and experience'. In the same way one might lack understanding and use of formal ploys but demonstrate an acute alertness to origins of feeling. While affirming Heaney's view of the ultimate interdependence of craft and technique, what these first two chapters examine specifically is Thomas's poetic technique, his habitual 'breaking the skin on the pool of himself', the process of unveiling 'his own reality'. 
In his 1972 article 'Belfast' Heaney also differentiates between the passivity and the activity required by the poet in pursuit of the self. $\mathrm{He}$ refers to his own listening for poems, to waiting and to hearing, much as Wordsworth did, but he also writes of seeking, of journeying, of dredging up, of overmastering, as he claims Yeats did. His conclusion is that poems

involve craft and determination, but chance and instinct have a role in the thing too. I think the process is a kind of somnambulist encounter between masculine will and intelligence and feminine clusters of image and emotion. (1980: 34)

This dichotomy is vital to an understanding of R. S. Thomas's poetry as autobiography. What Heaney refers to as the active masculine will and the passive feminine image are characteristics which recur in Thomas's poetry. And yet Thomas's poems are full of images of waiting as well. A reference to Keats can help here. In his famous 'Negative Capability' letter to his brothers in December 1817 Keats claims that the 'Man of Achievement' is able to suffer in partial knowledge, able to accept that he cannot, in this life, know himself fully, but has learned contentment with partial knowledge, with listening and waiting for what is yielded up from outside of his conscious power (1954: 53). Paradoxically, that apparent passivity, that listening in half-light is, for Keats, the key to literary achievement. The impulses at work are towards polar opposites, towards definitiveness and solidity as much as toward the darkness of unknowing. It is precisely according to these kinds of tensions and through these joined channels that I am suggesting Thomas approaches himself in poetry.

There is a paradoxically universal application of the project of the self in which the limitation necessary to the project is also the gateway to a kind of transcendence. Again, Charles Olson, while differing from Thomas in most aspects of theory and content, is closely in tune with this idea of a transcendence made available through the recognition of natural limits. In his 1950 essay 'Projective Verse' Olson asserts that

the use of a man, by himself and thus by others, lies in how he conceives his relation to nature, that force to which he owes his somewhat small existence. If he sprawl, he shall find little to sing but himself, and shall sing, nature has such paradoxical ways, by way of artificial forms outside himself. But if he stays inside himself, if he is contained within his nature as he is participant in the larger force, he will be able to listen, and his hearing through himself will give him secrets objects share. (1967: 60) 
Interestingly, Olson's singing by way of 'artificial forms' outside of the self is akin here to the overweighting of craft, the lack of technique pointed up by Heaney. But most importantly here, according to Olson, to have the ability to remain contained within one's individual nature and to express that nature within its boundaries is to achieve a transcendence into the larger world, is to receive 'the secrets objects share'. Similarly, the attempt on the part of the poet to achieve transcendence not only shatters that more proper containment but results in a dislocation, an artificiality, a dispersal of powers towards impotence and ultimately annihilation. W. B. Yeats reiterates the idea with great clarity in his 'Samhain: 1905':

If I had written to convince others I would have asked myself, not 'Is that exactly what I think and feel?' but 'How would that strike so-and-so? How will they think and feel when they have read it?' ... If we understand our own minds, and the things that are striving to utter themselves through our minds, we move others, not because we have understood or thought about those others, but because all life has the same root. Coventry Patmore has said, 'The end of art is peace', and the following of art is little different from the following of religion in the intense preoccupation it demands. (1962: 199)

'The things that are trying to utter themselves through our minds', and which address the one root of all life, are loosed, according to Yeats, not by an active pursuit of transcendence but by an almost religious attention to the ground falling within the more humble parameters of the self, what Thomas has referred to as his playing 'on a small pipe, a little aside from the main road' (Merchant 1990: 4). Thomas writes in his 'Autobiographical Essay' originally published in the Contemporary Authors: Autobiographical Series:

Was it a slight gift of Keats's negative capability that made it often so difficult for me to believe in my separate, individual existence? Certainly it has come to me many times with a catch in the breath that I don't know who I am. (1986: 20)

And yet a gift for Keats's negative capability does not imply a complete lack of self-knowledge so much as a partial and incomplete self-knowledge, a knowing and a not knowing. This is what characterises Thomas's project of the self: a knowing and a not knowing, an aggressive pursuit and standing off, a rage to master and a humble waiting, all finally resolving themselves into a quest inwards and downwards in which, as we shall 
see, the strenuous, active journey eventually gives way to a gentler turning aside.

The title of Barbara Prys-Williams's article "'A consciousness in quest of its own truth": Some Aspects of R. S. Thomas's The Echoes Return Slow as Autobiography' itself indicates this antipathy between knowing and unknowing which underlies Thomas's poetic project. In particular, Prys-Williams's use of the term 'quest' (originally by G. Gusdorf from whom the phrase in the title originates) is highly appropriate here. Prys-Williams writes that

Boundaries of the genre have expanded considerably beyond the limiting supposition that autobiography is coterminous with selfwritten biography. Theorists now allow that good autobiography may as fully communicate the sense of a life as the events of a life and that 'self-enacting, self-reflexive verbal structures' may be important means of communicating the feel of a life from inside, in areas in which discursive prose might be inherently inadequate. (1996: 98)

\section{Prys-Williams asserts that}

the poetic medium ... enables Thomas to explore fully his own sense of self, partly through allowing privileged access to the unconsciousness (and image-producing) part of his psyche, so important a determinant of the unique nature of his whole being.

What she so rightly points to in all of this is a poetic act that is autobiographical not in the sense of depiction of the 'finished' or 'unified' self but rather as exploration and discovery of the many, often contradictory selves of the individual as they reside within and, indeed, play between the conscious and unconscious layers of the poet's psyche. I would suggest that this exploration and discovery of an interior and often subconscious complexity is rooted in Jungian psychology. In the 'Prologue' to his autobiographical Memories, Dreams, Reflections (1961), composed when he was eighty-three, Jung writes:

My life is a story of the self-realisation of the unconscious. Everything in the unconscious seeks outward manifestation, and the personality too desires to evolve out of its unconscious conditions and to experience itself as a whole ... In the end the only events in my life worth telling are those when the imperishable world irrupted into this transitory one. That is why I speak chiefly 
of inner experiences, amongst which I include my dreams and visions ... All other memories of travels, people and my surroundings have paled beside these interior happenings ... But encounters with the 'other' reality, my bouts with the unconscious, are indelibly engraved upon my memory. In that realm there has always been wealth in abundance, and everything else has lost importance by comparison ... I can understand myself only in the light of inner happenings. It is these that make up the singularity of my life, and with these my autobiography deals. (1963: 17-19)

I would argue that this is precisely the project of the self that Thomas undertakes in poetry, the gradual self-realisation of the unconscious, the strenuous evolution towards wholeness, encounters or even 'bouts' with the 'other' reality. In this sense Thomas crosses a bridge as it were from an early affinity with Wordsworth and Tennyson to a more complicated project in keeping with ideas of Yeats's daimon and Pound's personae. What one finds in Thomas's poetry is increasingly a portrait of 'inner happenings' next to which the outward circumstances and more traditionally 'autobiographical' details of the poet's life become the mere setting of a more interior drama. Though Prys-Williams never suggests this link to Jung, she does write that 'For Thomas, then, autobiographical writing can be seen as an aid to consolidation of a self' and cites Paul J. Eakin's view of 'autobiography not merely as the passive, transparent record of an already completed self but rather as an integral and often decisive phase of the drama of self-definition' (1996: 101). Interestingly, Prys-Williams refers in this capacity to Sartre's The Words, in which the philosopher claims to have not rendered but discovered his identity through the very act of writing:

I was born of writing. Before that, there was only a play of mirrors. With my first novel, I knew that a child had got into the hall of mirrors. By writing I was existing ... I existed only in order to write and if I said 'I', that meant 'I who write'. (1996: 99)

In this wider light we can reassess what is commonly referred to as $\mathrm{R}$. $\mathrm{S}$. Thomas's 'autobiographical proseworks'. ${ }^{10}$ Although interesting and informative, the prosework is largely a record of the poet's exterior rather than interior life. As traditional autobiography it can be thought of as forming something of a shell, a definite and sometimes protective covering which houses the softer flesh of the poems within. Again, it must be kept in mind that while Thomas's identity clearly incorporates the important external factors of race, family, culture and geographic 
locations, and while those externals are very much reflected in the early poetry of the Manafon and Eglwysfach periods, it is the quest for a deeper sense of identity and belonging, for understanding of the interior and ultimate components of being, beyond those of the physical and exterior, which the project of the self in Thomas's poetry takes up. It is in the poems that he achieves his transparency of being, his complex display of the search for identity. The prosework forms mostly the solid framework of what Montaigne calls 'Fortune', within which the transparency of the poems has been achieved. None the less, as we shall see, the prosework can reveal important clues to the project of the self which Thomas undertakes in the poetry.

\section{Notes}

1 Speaking to the Conference of Library Authorities in Wales and Monmouthshire in 1968 in a lecture titled 'The Making of a Poem' Thomas said: 'I became rather tired of the themes about nationalism and the decay of the rural structure in Wales ... I can now think more about poetry and remember all the wonderful poems which I might have written and never will write if I had concentrated more on pure poetry and on the technique of poetry without pushing these themes and propagandas; without strutting and beating my chest and saying I am Welsh' (1969: 110).

2 Such descent into the land of the dead has a pertinent classical parallel in Virgil's The Aeneid, Book VI, in which Aeneas plucks the golden bough and descends into Hades to reunite with his dead father Anchises. The reunion can be seen as a touching of his source by Aeneas which fires him with resolve in his continuing journey on upper earth. The allusion is made use of by both Heaney and Thomas. See Heaney's 1991 collection Seeing Things and Thomas's poem 'First Person' in Mass for Hard Times (1992).

3 Breath plays a central role in Olson's theory of projective verse. In particular he argues that poetry must take up the 'possibilities of the breath, of the breathing of the man who writes as well as of his listenings' (1967: 51).

4 Also see Thomas's 'The Wood' from Experimenting with an Amen (1986) in which the man enters the labyrinthine wood of himself in search of his lost identity. The poem concludes: 'How many times / over must he begin again?' (16). Similarly, in The Echoes Return Slow (1988) Thomas refers to 'the slowness / of the illumination of the self' (103).

5 Note Thomas's allusion to the function of the Oracle at Delphi in 'The Reason' from Mass for Hard Times (1992). The poem is discussed in the final portion of the present chapter.

6 See 'Digging' from Heaney's first collection Death of a Naturalist (1966).

7 Even in 'Inside' from his Later Poems (1983), though Thomas describes himself as a geological phenomenon, the solidity and availability created by such an image is effectively counteracted by simultaneous use of opposing images of obscurity and transience. 
8 Thomas clearly echoes these sentiments in 'After Jericho' from Frequencies (1978):

There is an aggression of fact

to be resisted successfully

only in verse. (43).

9 This idea seems clearly related to the theory of masks one finds in Wilde and Yeats in which both protection and renewal can be achieved through the struggle towards connections with multiple identities. See Carol Christ's excellent treatment of this idea in her Victorian and Modern Poetics (1984).

10 Y Llwybrau Gynt (1972); an essay for Contemporary Authors: Autobiographical Series (1986); Neb (1985); Blwyddyn yn Lleyn (1990); ABC Neb (1995). 